\title{
ANALISIS PERHITUNGAN PAJAK PENGHASILAN PASAL 21 PEGAWAI TETAP DAN PENETAPAN AKUNTNASI PADA PT. BANK SULUTGO (PERSERO) TBK. CABANG UTAMA
}

\author{
Seruni J. Prang ${ }^{1}$, Sifrid S. Pangemanan ${ }^{2}$, Harijanto Sabijono ${ }^{3}$ \\ ${ }^{1,2,3}$ Fakultas Ekonomi dan Bisnis . Jurusan Akuntansi. Universitas Sam Ratulangi, Jl. Kampus Bahu, Manado, \\ 95115, Indonesia \\ E-mail: seruniprang@gmail.com
}

\begin{abstract}
Income tax article 21 is a tax on income which becomes the obligation of taxpayer to pay for it. Income in the form of salary, honorarium, allowances and other payments with any name in connection with the work, services or activities undertaken by the taxpayer of a domestic individual. The law used to regulate the amount of tax rates, the procedure of payment and tax reporting is the law No. 36 of 2008. The purpose of this study is to find out how to analyze the calculation of income tax article 21 fixed employment and accounting application of PT. Bank SulutGo (Persero) Tbk. Cabang Utama. The method of analysis used in this research is descriptive method that is discussing the problem by collecting, deciphering, calculating, comparing and explaining a situasion so that it can be drawn conclusion covering the calculation of pph article 21 and accounting for permanent employees at PT. Bank SulutGo (Persero). Based on the results of the study found that the calculation of income tax article 21 at PT. Bank SulutGo (Persero), is in compliances with the new taxation legislation, namely law no. 36 of 2008 on income tax and the regulation of the director general of tax number PER-16/PJ/2016.
\end{abstract}

Keywords: accounting, income tax article 21

\section{PENDAHULUAN}

Perpajakan adalah salah satu perwujudan dari peran serta warga negara sebagai wajib pajak yang secara langsung dan bersama-sama melaksanakan kewajiban perpajakan yang akan digunakan untuk membiayai segala keperluan negara dan pembangunan nasional. Bagi negara pajak merupakan sumber penerimaan penting yang akan digunakan untuk membiayai negara baik pengeluaran rutin maupun pengeluaran pembangunan. Dari segi ekonomi pajak merupakan pemindahan sumber daya dari perusahaan ke sektor publik. Pemindahan sumber daya tersebut akan mempengaruhi daya beli atau kemampuan belanja perusahaan.

Pembangunan nasional merupakan kegiatan yang berkesinambungan dengan tujuan utamanya adalah untuk meningkatkan kesejahteraan rakyat. Pembangunan ini dapat berjalan dengan lancar apabila ada sumber dana yang mendukung pelaksanaannya.Menurut APBN sumber pendapatan terbesar yaitu sektor perpajakan, meskipun masih banyak sektor lain seperti minyak dan gas bumi serta bantuan luar negeri. Hal ini dibuktikan ketika negara kita dilanda krisis, pemasukan dari sektor pajak ternyata terus meningkat dibandingkan dengan sektor lainnya.

Peran pajak bagi negara Indonesia berfungsi sebagai alat penerimaan negara dan berfungsi sebagai pengatur atau sebagai penyelaras kegiatan ekonomi pada masa yang akan datang. Fungsi pajak yang pertama inilah yang menjadikan pajak sebagai andalan pemerintah untuk menghasilkan penerimaan yang setinggitingginya dari sektor pajak.

Untuk melaksanakan kewajiban perpajakan, wajib pajak harus memahami ketentuanketentuan umum perpajakan. Salah satu ketentuan tersebut yaitu mengenai Self Assessment System. Dalam Self Assessment System seluruh proses pelaksanaan kewajiban perpajakan dimulai dari menghitung dan menetapkan besarnya pajak terutang, menyetorkan pajak 
terutang ke kas negara, melaporkan perhitungan dan penyetoran serta mempertanggungjawabkan semua kewajiban yang dilakukan oleh Wajib Pajak. Salah satu jenis pajak penghasilan yang menggunakan Withholding System yaitu Pajak Penghasilan $(\mathrm{PPh})$ pasal 21. PPh. pasal 21 merupakan pajak terutang atas penghasilan yang menjadi kewajiban wajib pajak untuk membayarnya. Penghasilan yang dimaksud berupa gaji, honorarium, tunjangan dan pembayaran lain dengan nama apapun sehubungan dengan pekerjaan, jasa atau kegiatan yang dilakukan oleh Wajib Pajak orang pribadi dalam negeri. Undang-undang yang dipakai untuk mengatur besarnya tarif pajak, tata cara pembayaran dan pelaporan pajak yaitu Undang-Undang No.36 tahun 2008 yang merupakan penyempurnaan bagi undangundang terdahulu yaitu Undang-Undang No.17 tahun 2000, yang sah diberlakukan per tanggal 1 Januari 2009.

PT. Bank Bank SulutGo (Persero) Tbk. Cabang Utama mempunyai jumlah pegawai dengan spesifikasi Pegawai Tetap dan Pegawai Tidak Tetap, sehingga memiliki potensi yang besar dalam membayar pajak khususnya Pajak Penghasilan Pasal 21. Selain itu, PT. Bank SulutGo (Persero) Tbk. Cabang Utama juga berpotensi terhadap penyimpangan baik perhitungan maupun pelaporan Pajak Penghasilan yang diakibatkan oleh perbedaan pandangan atas Undang-Undang Pajak Penghasilan. Hal ini juga berpengaruh dalam pencatatan akuntansi, karena kekeliruan dalam perhitungan akan menyebabkan kesalahan dalam pencatatan akuntansi. Tujuan dari penelitian ini yaitu untuk mengetahui Perhitungan Pajak Penghasilan Pasal 21 Pegawai Tetap dan Penerapan Akuntansi pada PT. BANK SULUTGO (Persero) Tbk. Cabang Utama

\section{TINJAUAN PUSTAKA \\ Konsep Akuntansi}

Menurut Charles T. Horngern dan Walter T. Harrison (2012:4) menyatakan bahwa: Akuntansi adalah sistem informasi yang mengukur aktivitas bisnis, memproses data menjadilaporan, dan mengkomunikasikan hasilnya kepada para pengambilan keputusan. Dari definisi-definisi diatas dapat disimpulkan bahwa akuntansi secara umum yaitu sistem informasi yang memberikan laporan kepada pihak-pihak yang berkepentingan mengenai kegiatan ekonomi dan kondisi perusahaan. Akuntansi adalah sebagai proses pencatatan, penggolangan, peringkasan transaksi keuangan dan penginterpretasikan hasil proses tersebut.

\section{Konsep Pajak}

Definisi pajak menurut Undang-Undang No. 28 tahun 2007 tentang Ketentuan Umum dan Tatacara Perpajakan yaitu : "Pajak adalah kontribusi wajib kepada negara yang terutang oleh orang pribadi atau badan yang bersifat memaksa berdasarkan undang-undang dengan tidak mendapatkan imbalan secara langsung dan digunakan untuk keperluan negara bagi sebesar-besarnya kemakmuran rakyat”.

\section{Konsep Akuntansi Pajak}

Konsep akuntansi pajak menurut Djoko Muljono (2013:2), akuntansi pajak adalah bidang akuntansi yang berkaitan dengan perhitungan perpajakan, yang mengacu pada peraturan, undang-undang dan aturan pelaksanaan perpajakan. Prinsip-prinsip yang diakui dalam akuntansi perpajakan meliputi : kesatuan akuntansi, kesinambungan, harga pertukaran yang objektif, konsistensi, konservatif. Fungsi akuntasi pajak adalah mengolah data kuantitatif untuk menyajikan laporan keuangan yang memuat perhitungan perpajakan yang kemudian akan digunakan sebagai pertimbangan pengambilan keputusan. Tujuan kualitatif dalam akuntansi pajak adalah : relevan, dapat dimengerti, daya uji, netral, tepat waktu, daya banding dan lengkap. 


\section{Pajak Penghasilan PPh Pasal 21}

Menurut Undang-Undang Nomor 36 Tahun 2008, Pajak Penghasilan adalah pajak yang dikenakan atas penghasilan berupa gaji, upah, honorarium, tunjangan dan pembayaran lain yang diterima oleh Wajib Pajak Orang Pribadi dalam negeri sehubungan dengan pekerjaan, jasa dan kegiatan. Pajak Penghasilan merupakan pajak yang dibebankan pada penghasilan perorangan, perusahaan atau badan hukum lainnya. Pajak Penghasilan bisa diberlakukan progresif, proporsional atau regresif.

\section{Objek Pajak Penghasilan}

Menurut Mardiasmo (2011:139), yang menjadi objek pajak adalah penghasilan, yaitu setiap tambahan kemampuan ekonomis yag diterima atau diperoleh Wajib Pajak, baik yang berasal dari Indonesia maupun dari luar Indonesia, yang dapat dipakai untuk konsumsi atau untuk menambah kekayaan Wajib Pajak yang bersangkutan, dengan nama dan dalam bentukapa pun, termasuk :

1. Penggantian atau imbalan berkenaan dengan pekerjaan atau jasa yang diterima atau diperoleh termasuk gaji, upah, tunjangan, penghasilan, komisi, bonus, gratifikasi, uang pensiun atau imbalan dalam bentuk lainnya, kecuali ditentukan lain dalam undangundang ini.

2. Hadiah dari undian atau pekerjaan atau kegiatan dan penghargaan.

3. Laba usaha.

4. Keuntungan karena penjualan atau karena pengalihan harta termasuk :

a. Keuntungan karena pengalihan harta kepada perseroan, persekutuan dan badan lainnya sebagai pengganti saham atau penyertaan modal.

b. Keuntungan karena pengalihan harta kepada pemegang saham, sekutu atau anggota yang diperoleh perseroan, persekutuan dan badan lainnya.

c. Keuntungan karena likuisasi, penggabungan, peleburan, pemekaran, pemecahan, pengmbilalihan usaha atau reorganisasi dengan nama dan dalam bentuk apa pun.

d. Keuntungan karena pengalihan harta berupa hibah, bantuan atau sumbangan, kecuali yang diberikan kepada keluarga sedarah dalam garis keturunan lurus satu derajat dan badan keagamaan, badan pendidikan, badan sosial termasuk yayasan, koperasi atau orang pribadi yang menjalankan usaha mikro dan kecil yang ketentuannya diatur lebih lanjut dengan Peraturan Menteri Keuangan, sepanjang tidak ada hubungan dengan usaha, pekerjaan, kepemilikan atau penguasaan di antara pihak-pihak yang bersangkutan.

e. Keuntungan karena penjualan atau pengalihan sebagian atau seluruh hak penambangan, tanda turut serta dalam pembiayaan atau permodalan dalam usaha pertambangan.

5. Penerimaan kembali pembayaran pajak yang telah dibebankan sebagai biaya dan pembayaran tambahan pengembalian pajak.

6. Bunga termasuk premium, diskonto dan imbalan karena jaminan pengembalian utang.

7. Dividen, dengan namadan dalam bentuk apapun, termasuk dividen dari perusahaan asuransi kepada pemegang polis dan pembagian sisa hasil usaha koperasi.

8. Royalti atau imbalan atas penggunaan hak.

9. Sewa dan penghsilan lain sehubungan degna penggunaan harta.

10. Penerimaan atau perolehan pembayaran berkala.

11. Keuntungan karena pembebasan utang, kecuali sampai dengan jumlah tertentu yang ditetapkan dengan Peraturan Pemerintah.

12. Keuntungan selisih kurs mata uang asing.

13. Selisih lebih karena penilaian kembali aktiva.

14. Premi asuransi. 
15. Iuran yang diterima atau diperoleh perkumpulan dari anggotanya yang terdiri dari Wajib Pajak yang menjalankan usaha atau pekerjaan bebas.

16. Tambahan kekayaan neto yang berasal dari penghasilan yang belum dikenakan pajak.

17. Penghasilan dari usaha berbasis syariah.

18. Imbalan bunga sebagaimana dimaksud dalam undang-undang yang mengatur mengenai ketentuan umum dan tata cara perpajakan, dan

19. Surplus Bank Indonesia.

\section{Tarif Pajak Penghasilan (PPh) pasal 21}

Tarif Pajak Penghasilan (PPh) Pasal 21 Direktorat Jenderal Pajak telah menerbitkan Peraturan Direktorat Jenderal Pajak Nomor PER- 31/PJ/2009 tentang pedoman teknis tata cara pemotongan, penyetoran dan pelaporan Pajak Penghasilan Pasal 21 sehubungan dengan pekerjaan, jasa dan kegiatan orang pribadi. Peraturan tersebut merupakan petunjuk pelaksanaan dari Menteri Keuangan-252/PMK.03/2008, tentang petunjuk pemotongan atas penghasilan sehubungan dengan pekerjaan, jasa dan kegiatan orang pribadi. Untuk menghitung Pajak Penghasilan Pasal 21, terlebih dahulu diketahui dasar pengenaan pajaknya. Untuk Wajib Pajak dalam negeri dan Badan Usaha Tetap, yang menjadi dasar pengenaan pajakya adalah Penghasilan Kena Pajak. Pajak penghasilan bagi Wajib Pajak dihitung dengan cara mengalikan Penghasilan Kena Pajak dengan tarif pajak sesuai dalam Undang-Undang Pajak Penghasilan Pasal 17 didasarkan pada tarif Progresif, yaitu tarif yang didasarkan pada lapisan Penghasilan Kena Pajak, yang artinya persentase tarif yang digunakan semakin besar jika jumlah yang dikenakan pajak semakin besar. Adapun tarif Pasal 17 Undang-Undang Pajak Penghasilan, yaitu :

Tabel 1 : Daftar Tarif Pajak Penghasilan

\begin{tabular}{cll}
\hline Lapisan & \multicolumn{1}{c}{ Lapisan Penghasilan Kena Pajak } & Tarif \\
\hline I & s.d Rp 50.000.000 & $5 \%$ \\
II & Di atas Rp 50.000.000 s.d Rp 250.000.000 & $15 \%$ \\
III & Di atas Rp 250.000.000 s.d Rp 500.000.000 & $25 \%$ \\
IV & Di atas Rp 500.000.000 & $30 \%$ \\
\hline
\end{tabular}

Sumber : Peraturan Direktur Jenderal Pajak Nomor PER-16/PJ/2016

Penghasilan Tidak Kena Pajak (PTKP) Besarnya tarif Penghasilan Tidak Kena Pajak (PTKP) terhitung 1 Januari 2015 Berlaku sebagai berikut :

Tabel 2: Tarif Penghasilan Tidak Kena Pajak (PTKP)

\begin{tabular}{clcc}
\hline No. & Uraian & Setahun $(\mathrm{Rp})$ & Sebulan (Rp) \\
\hline I & Untuk Wajib Pajak Orang Pribadi & $54.000 .000,-$ & 4.500 .000 \\
II & Tambahan untuk pegawai yang kawin & $4.500 .000,-$ & 375.000 \\
III & Tambahan setiap anggota keluarga & $4.500 .000,-$ & 375.000 \\
& sedarah dan semenda dalam garis & & \\
& keturunan lurus serta anak angkat & & \\
& yang menjadi tanggungan sepenuhnya & & \\
& paling banyak 3 orang untuk setiap & & \\
& keluarga & $54.000 .000,-$ & 4.500 .000 \\
IV & Tambahan untuk seorang istri & & \\
& yang penghasilannya digabung dengan & & \\
& penghasilan suami & & \\
\hline Sumber :Peraturan Direktur Jenderal Pajak Nomor PER $16 / P J / 2016$
\end{tabular}

Sumber :Peraturan Direktur Jenderal Pajak Nomor PER-16/PJ/2016 


\section{METODE PENELITIAN}

\section{Jenis dan sumber data}

Data merupakan sekumpulan informasi yang didapat dari sebuah penelitian untuk kemudian digunakan dalam menganalisa permasalahan yang dihadapi dan pada akhirnya mencari solusi sebagai pemecahan.

Jenis data yang dipergunakan dalam penelitian ini, yaitu:

1. Data Kualitatif, yaitu data yang disajikan secara deskriptif atau terbentuk uraian seperti : sejarah singkat perusahaan, struktur organisasi dan job description, dokumen-dokumen, serta Undang-undang dan peraturan-peraturan yang berkaitan dengan PPh pasal 21.

2. Data Kuantitatif, yaitu data yang disajikan dalam bentuk angka-angka atau bilangan yang dapat dihitung dan dapat dibandingkan yang satu dengan yang lainnya.

Sumber data dalam penelitian ini, yaitu :

1. Data Primer

2. Data Sekunder

\section{Metode Pengumpulan Data}

Dalam penelitian ini, metode yang dilakukan dalam usaha mengumpulkan data dan informasi yaitu :

1. Penelitian lapangan (Field Researd Method). Dalam melakukan riset lapangan, penulis mengambil data-data langsung dari sumber data, sebagai pembanding untuk memproses keterangan dan kenyataan yang sebenarnya.

Penelitian lapangan dilakukan dengan cara :

a. Pengamatan (Observasi)

b. Wawancara (Interview)

2. Penelitian kepustakaan (Litbang Researd Method). Dalam melakukan riset menggunakan data-data kepustakaan yaitu buku-buku cetak, serta Undang-undang dan peraturan yang berkaitan dengan PPh Pasal 21 dan jurnal-jurnal, guna menyempurnakan penelitian.

\section{Metode analisis Data}

Metode analisis data yang digunakan dalam penelitian ini adalah metode deskriptif, yaitu membahas masalah dengan cara mengumpulkan, menguraikan, menghitung, dan membandingkan suatu keadaan serta menjelaskan suatu keadaan sehingga dapat ditarik kesimpulan yang meliputi Perhitungan Pajak Penghasilan Pasal 21 Pegawai Tetap dan Penerapan Akuntansi pada PT. BANK SULUTGO (Persero) Tbk. Cabang Utama

\section{Definisi Operasional}

Sesuai dengan judul penelitian yaitu : "Analisis Perhitungan Pajak Penghasilan Pasal 21 Pegawai Tetap dan Penerapan Akuntansi pada PT. BANK SULUTGO (Persero) Tbk. Cabang Utama" maka perlu dijelaskan arti dari judul adalah sebagai berikut :

1. Analisis adalah suatu usaha yang dilakukan secara mendetail mengetahui suatu objek yang akan diteliti.

2. Pajak Penghasilan pasal 21 adalah pajak atas penghasilan berupa gaji, upah, penghasilan, tunjangan, dan pembayaran lain yang diterima atau diperoleh Wajib Pajak Orang Pribadi dalam negeri sehubungan dengan pekerjaan atau jabatan, jasa, dan kegiatan.

3. Akuntansi adalah pengukuran, penjabaran, atau pemberian kepastian mengenai informasi yang akan membantu manajer, investor, otoritas pajak dan pembuat keputusan lain untuk membuat alokasi sumber daya keputusan di dalam perusahaan, organisasi, dan lembaga pemerintah. 
Secara keseluruhan yang dimaksud dengan judul penelitian ini yaitu untuk menganalisis bagaimana perlakuan akuntansi dan penerapannya dalam melakukan perhitungan Pajak Penghasilan Pasal 21 pegawai tetap di PT. BANK SULUTGO (Persero) Tbk. Cabang Utama

\section{HASIL ANALISIS DAN PEMBAHASAN}

\section{Hasil analisis}

Saat ini PT. BANK SULUTGO (Persero) Tbk. Cabang Utama memiliki karyawan dengan mengklasifikasikan karyawan ke dalam tiga kelompok, yaitu : Pegawai Tetap, Pegawai Tidak Tetap dan Pegawai Kontrak Pihak Ketiga. Untuk pegawai tidak tetap perusahaan memperkerjakan mereka berdasarkan sistem kontrak, dengan masa kontrak selama dua tahun.

Dalam penelitian ini dibatasi pada PPh Pasal 21 atas penghasilan pegawai tetap dan digunakan 10 karyawan sebagai sampel yang disimbolkan dengan L untuk karyawan laki-laki dan P untuk karyawan Perempuan. Selama tahun 2016 tidak terjadi kenaikan gaji. Untuk menghitung PPh Pasal 21 atas penghasilan Pegawai Tetap pada PT. BANK SULUTGO (Persero) Tbk. Cabang Utamatahun 2016, maka dapat menggunakan daftar penghasilan sebagai berikut :

Tabel 4.1 : Daftar Penghasilan Pegawai Tetap PT. BANK SULUTGO (Persero) Tbk. CabangUtamaBulan Januari 2016

\begin{tabular}{|c|c|c|c|c|}
\hline No. & $\begin{array}{c}\text { Nama Pegawai } \\
\text { Tetap }\end{array}$ & $\begin{array}{c}\text { Jenis } \\
\text { Kelamin }\end{array}$ & Status & $\begin{array}{c}\text { Penghasilan Bruto } \\
(\text { Rp) }\end{array}$ \\
\hline 1. & L1 & L & K/3 & $8.018 .846,-$ \\
\hline 2. & L2 & L & K/2 & $6.667 .800,-$ \\
\hline 3. & L3 & L & K/1 & $7.708 .200,-$ \\
\hline 4. & L4 & L & K/0 & $5.557 .430,-$ \\
\hline 5. & L5 & L & TK & $6.544 .443,-$ \\
\hline 6. & P1 & P & K/0 & $5.656 .700,-$ \\
\hline 7. & P2 & P & K/1 & $8.554 .900,-$ \\
\hline 8. & P3 & P & K/2 & $7.750 .850,-$ \\
\hline 9. & P4 & P & K/3 & $4.445 .620,-$ \\
\hline 10. & P5 & TK & \\
\hline
\end{tabular}

Sumber : PT. BANK SULUTGO (Persero) Tbk. Cabang Utama.

Berdasarkan daftar penghasilan pada tabel 4.1, maka dapat dihitung PPh Pasal 21 per bulan untuk pegawai tetap L1 sebagai berikut :

Penghasilan bruto bulan Januari $2016=\mathrm{Rp} 8.018 .846,-$

Penghasilan bruto tahun $2017=$ Rp.8.018.846,- $\mathrm{x} 12=\mathrm{Rp} .96 .226 .152,-$

Pengurang Penghasilan :

PTKP setahun

Untuk Wajib Pajak sendiri $\quad=$ Rp 54.000.000,-

Tambahan Wajib Pajak Kawin $\quad=$ Rp 4.500.000,- 
Tambahan Anak (3 anak $\times \operatorname{Rp~4.500.000,-)~}=\mathrm{Rp} \mathrm{13.500.000,-}$

Penghasilan Kena Pajak (PKP)

$=\underline{(\mathrm{Rp} 72.000 .000,-)}$

$=\operatorname{Rp~24.226.152,-}$

PPh Pasal 21 terutang :

Lapisan I = 5\% × Rp 24.226.152,- = Rp 1.211.307,-

PPh Pasal 21 sebulan $=$ Rp 1.211.307 : $12=$ Rp 100.942,-

Maka, jurnal akuntansi untuk pegawai tetap Rendy adalah sebagai berikut :

Biaya Gaji

Hutang PPh Pasal 21

Kas

Rp 8.018.846,-

Rp 100.942,-

Rp 7.917.904,-

Dan pada saat akan disetorkan ke kas negara, jurnal dicatat sebagai berikut :

Hutang PPh Pasal 21

Kas

Rp100.942,-

Rp100.942,-

Pencatatan ayat jurnal di atas adalah pencatatan terhadap Pajak Penghasilan Pasal 21 yang telah dipotong dan disetorkan oleh pemberi kerja atas penghasilan yang diterima atau diperoleh sehubungan dengan pekerjaan dari satu pemberi kerja yang merupakan pelunasan pajak yang terutang untuk tahun pajak yang bersangkutan.

\section{Pembahasan}

Pajak Penghasilan Pasal 21 adalah pajak atas penghasilan berupa gaji, upah, penghasilan, tunjangan dan pembayaran lainnya sehubungan dengan atau jabatan, jasa dan kegiatan yang dilakukan oleh Orang Pribadi, sebagaimana yang dimaksud dalam pasal 21 Undang-Undang Pajak Penghasilan. Pegawai adalah orang pribadi yang bekerja pada pemberi kerja, baik sebagai pegawai tetap atau pegawai tidak tetap/tenaga kerja lepas berdasarkan perjanjian atau kesepakatan kerja baik secara tertulis maupun tidak tertulis, untuk melaksanakan suatu pekerjaan dalam jabatan atau kegiatan tertentu dengan memperoleh imbalan yang dibayarkan berdasarkan periode tertentu, penyelesaian pekerjaan, atau ketentuan lain yang ditetapkan pemberi kerja.

Perusahaan dalam hal ini PT. BANK SULUTGO (Persero) Tbk. Cabang Utama mengimplementasikan perhitungan PPh Pasal 21 terhadap penghasilan pegawai tetap sesuai dengan peraturan perundang-undangan, berdasarkan hasil penelitian tidak ditemukan adanya kesalahan dalam perhitungan dan pemotongan PPh pasal 21.

\section{KESIMPULAN DAN SARAN}

\section{Kesimpulan}

Berdasarkan penelitian yang telah dilakukan pada PT. Bank SulutGo (Persero) Tbk. Cabang Utama dan pembahasan pada bab sebelumnya, maka kesimpulan yang dapat di ambil oleh peneliti dalam penelitian ini adalah : Perhitungan Pajak Penghasilan Pasal 21 pada Bank Rakyat Indonesia Cabang Manado, belum sepenuhnya sesuai dengan peraturan perpajakan yang baru yaitu Undang-Undang Nomor 36 Tahun 2008 tentang Pajak Penghasilan.

\section{Saran}

1. Bagian administrasi akuntansi perlu memperbaharui setiap peraturan perundangan yang baru mengenai perpajakan dan mengikuti setiap sosialisasi peraturan perundangan perpajakan yang dilakukan oleh kantor pajak sehingga tidak terjadi kesalahan potong baik lebih bayar atau kurang bayar yang mengakibatkan kesalahan pembayaran gaji pegawai. 
2. Perlunya pengetahuan tentang perpajakan minimal tentang PPh Pasal 21 agar pegawai dapat mengecek kembali apakah potongan atas pajak yang tercantum dalam daftar gajinya telah sesuai dengan ketentuan atau tidak.

3. Status untuk pegawai tetap yang sudah menikah perlu dicantumkan status suami/istri bekerja.

\section{DAFTAR PUSTAKA}

Brotodiharjo R. Santoso. (2007). Pengantar Ilmu Hukum Pajak. Bandung Penerbit : PT. Rafika Aditama.

Djoko Mulyono. (2011). Panduan Brevet Pajak Pajak Penghasilan. Yogyakarta. Penerbit : Andi.

Djoko Mulyono, 2009. Tax Planning Menyiasati Pajak Dengan Bijak. Yogyakarta. Penerbit Andi.

Dwi Sunar Prasetyono (2011), Panduan Lengkap Tata Cara dan Perhitungan PajakPenghasilan. Yogyakarta. Penerbit : Laksana.

Edy Suprianto (2011), Akuntansi Perpajakan. Yogyakarta. Penerbit : Graha Ilmu.

Emilia S. (2007) Evaluasi Perhitungan PPh Pasal 21 atas Gaji Karyawan pada PT. Federal International Finance Malang

Lili M. Sadeli. (2010). Dasar-Dasar Akuntansi. Jakarta. Penerbit : PT. Bumi Aksara.

Mardiasmo. (2011), Perpajakan Edisi Revisi 2011. Yogyakarta. Penerbit : Andi.

Mardiasmo. (2010), Perpajakan Edisi Revisi 2010. Yogyakarta. Penerbit : Andi.

Mienati Somya Lasmana dan Budi Setiorahardjo. (2010). Cara Perhitungan Pemotongan PPh Pasal 21. Yogyakarta. Penerbit : Graha Ilmu

Smith dan Skousen. (2009). Akuntansi Keuangan. Yogyakarta. Penerbit : Salemba Empat.

Sidyanto. (2005). Sistem Administrasi Pajak Penghasilan Pasal 21 di PT. (Persero) Pertamina Unit Pemasaran VII Semarang.

Trisnawati (2007), Akuntansi Perpajakan. Yogyakarta. Penerbit : Andi.

Departemen Keuangan Republik Indonesia Direktorat Jenderal Pajak Tahun 2008.

Perbandingan Susunan Dalam Satu Naskah Undang-Undang Ketentuan Umum dan

Tata Cara Perpajakan Beserta Peraturan-Peraturan Pelaksanaannya Direktorat Penyuluhan Pelayanan dan Humas.

Undang-Undang RI Nomor 36 Tahun 2008 Tentang Perubahan Atas Undang-Undang Nomor 7 Tahun 1983 Mengenai Pajak Penghasilan. 